DOI: $10.20472 / S S .2015 .4 .4 .003$

\title{
PHENOMENA OF SOCIAL INNOVATION: PRACTICAL ATTEMPTS FROM SLOVAKIA
}

\author{
JAROSLAVA KOVÁČOVÁ
}

\begin{abstract}
:
A social innovation represents unusual inspirational ideas to various kinds of social problems which are more effective, efficient, sustainable, or introduce solutions for which the value created arises primarily to society as a whole rather than private individuals. The term social innovation is not very well known in Slovakia yet. Although it exists and develops, it is still more often spread as social affairs, social policy, or the third sector activities. This article brings an overview of social innovation definitions and describes how the free flow of ideas, values, roles, and relationships across sectors is enhancing the social innovation. Further we introduce the understanding of social innovation in Slovakia on a few chosen examples from various sectors. At last we suggest ways to continue dismantling the barriers between the sectors through collaboration between government, non-profit and business sector $\square$ to create new and lasting solutions to the most nettlesome social problems of our times.
\end{abstract}

\section{Keywords:}

Slovakia, social innovation, social policy, sustainability, governance

JEL Classification: A13, O31, M14

\section{Authors:}

JAROSLAVA KOVÁČOVÁ, University of Economics in Bratislava, Slovakia, Email: jaroslava.kovacova@euba.sk

\section{Citation:}

JAROSLAVA KOVÁČOVÁ (2015). Phenomena of Social Innovation: Practical attempts from Slovakia. International Journal of Social Sciences, Vol. IV(4), pp. 30-41., 10.20472/SS.2015.4.4.003 


\section{Introduction}

Social innovations can be defined as new strategies, products, services and organizations that simultaneously meet social needs of all kinds (more effectively than other alternatives), create new social relationships, collaborations and enhance civil society. According to Murray et al. (2010) this kind of innovations are considered to be both good for society and capable of enacting greater societal involvement.

The term social innovation can be considered as relatively recent, dating back at most a decade or two, but the concept itself describes a phenomenon that is as old as human societies themselves (Schumpeter, 1934; Kuznets, 1974; Pol, 2009; Hochgerner, 2012). With the time passing, the description of social innovation related mainly to social enterprise and social entrepreneurship, technological innovation, corporate social responsibility and open innovation, active involvement of citizens, which is effective mainly in addressing the challenges of environmental issues, education problems, social justice, social and health care, unemployment, ageing, etc.

The concept of social innovation is becoming increasingly evident in policy, scientific and public debates. There is a growing consensus among practitioners, policy makers and the research community that widespread social innovation is required to cope with the significant challenges that societies are facing now and will face in the future. The impetus for this revival is being driven by new projects, joint actions, initiatives, and efforts to establish innovation (Howaldt et al., 2014). Mulgan (2012) however indicates, whereas there are many theoretical foundations which help to envisage the field, a consistent theoretical foundation of social innovation is still absent.

In the following parts of our paper we will discuss the different perspectives, emphases and ways of social innovation through a theoretical and practical angle, and in turn provide our own understanding of this broad topic.

\section{Social innovation in the literature review}

There is a growing interest in social innovation both in academic and public discourse. Although the term had been used previously, researches and publications on social innovation have increased in recent years, which can be connected to a number of factors, including a growing dissatisfaction with the emphasis on technological impact in economic innovation literature and innovation policy (Caulier-Grice et al., 2012).

However, a common definition of the term social innovation itself has not yet emerged. Some authors describe social innovations as "new ideas that work to meet pressing unmet needs and improve peoples' lives" (Mulgan et al., 2007) or similarly as "the process of inventing, securing support for, and implementing novel solutions to social 
needs and problems" (Stanford Social Innovation Review, 2006, Phills et al., 2008), others introduce them as changes in human structure and organization (Simms, 2006).

The OECD's LEED Forum on Social Innovations (2011) explains social innovation as distinct from economic innovation, because "they do not introduce new types of production or exploiting new markets for the sake of exploiting them, but is about satisfying new needs not provided by the market (even if markets intervene later) or creating new, more satisfactory ways of insertion in terms of giving people a place and a role in production". In addition, the Forum states that social innovation seeks new answers to social problems by: identifying and delivering new services that improve the quality of life of individuals and communities and identifying and implementing new labour market integration processes, new competencies, new jobs, and new forms of participation, as diverse elements that each contribute to improving the position of individuals in the workforce.

According to the European Union policy perspective, the concept of social innovation is important because it responds to the need for cohesion of a particular society, which is an objective for public policy as well as civil society initiatives (European Commission, 2013).

As seen from this short review, the scholars and writers on social innovation represent different fields, including social sciences, business administration, economics, social work and political science. As a consequence, the interpretation of the term social innovation is not unitary: it diverges across various research fields.

Some interpretations are very narrow and do not include many examples of social innovation (especially those market-driven), while others are so broad that they describe projects or organizations that are not particularly innovative, although they are in some way social. Social innovation is by its nature a multi-disciplinary practice-led field, which has undoubtedly contributed to the diversity of meanings, understandings, and uses of the term itself.

By its very nature, social innovation as the field matures, which will undoubtedly continue to provoke debates and ways of looking at social innovation in different sectors worldwide to shape the theory, research, empirical understandings and policy recommendations.

Table 1 brings a literature overview on the term social innovation and its common uses. 
Table 1: Summary of five broad uses of the term social innovation

\begin{tabular}{|c|c|}
\hline Examples of uses & Concrete literature topics \\
\hline $\begin{array}{l}\text { Processes of social change } \\
\text { and societal transformation }\end{array}$ & $\begin{array}{l}\text { - Role of civil society in social change } \\
\text { - } \text { Role of social economy and social entrepreneurs } \\
\text { - } \text { Role of businesses in social change }\end{array}$ \\
\hline $\begin{array}{l}\text { New products, services and } \\
\text { programmes }\end{array}$ & $\begin{array}{l}\text { - Public sector innovation } \\
\text { - Public service provision by social enterprises and } \\
\text { civil society organisations }\end{array}$ \\
\hline Social entrepreneurship & $\begin{array}{l}\text { - Role of individuals in creating social ventures } \\
\text { - Behaviours and attitudes related to social } \\
\text { enterprises } \\
\text { - Businesses focused on social objectives with any } \\
\text { surpluses re-invested }\end{array}$ \\
\hline $\begin{array}{l}\text { Business strategy and } \\
\text { organizational management }\end{array}$ & $\begin{array}{l}\text { - Human, institutional and social capital } \\
\text { - Organizational efficiency, leadership and } \\
\text { competitiveness } \\
\text { - Sustainability and effectiveness of non-profit } \\
\text { organisations }\end{array}$ \\
\hline $\begin{array}{l}\text { Governance and capacity } \\
\text { building }\end{array}$ & $\begin{array}{l}\text { - Interrelationships between actors and their skills, } \\
\text { competencies, assets and social capital in } \\
\text { developing programmes and strategies }\end{array}$ \\
\hline
\end{tabular}

Source: The Young Foundation (2012), p. 8

\section{Practical examples on social innovation from Slovakia}

\subsection{Basic foreword and contextual issues}

According to the European Innovation Scoreboard (2014), Slovakia is one of the lowest ranked countries for innovation performance in general. Despite higher ranking (above the EU average) on human resources, the opposite is true when it concerns open excellent research systems, financial performance or intellectual assets.

When explaining social innovation issues in Slovakia, the fact that the word "social" has a common root with "socialism" should be taken into account, evoking rather negative affiliation to people due to the historical reasons. After the fall of Communism, the free market principle was applied to almost all areas of life - from industry, banking and finance to cultural, social and even societal issues. The transition in the 1990s brought the re-establishment of the economy, coupled with reform processes and also a greater unemployment and economic hardship accompanied by an upsurge of corruption and cronyism carried out by all types of political elites. (Olejárova, 2013). In the past few years Slovakia has recovered from the global economic crisis, but it still has a long way to 
go "notably identifying domestic drivers of growth and implementing policies for sustainable improvements." (OECD, 2014).

The reduction of unemployment, thesupport for the long-term unemployed, young people and the unemployed Roma minority to find their way back to the labour market, while fostering long-term growth, which is also beneficial to marginalized segments of society: these are the most challenging issues in Slovakia requiring a greater reliance on social innovation Therefore, a stronger emphasis and understanding that all actors in society are very important is slowly arising into awareness of population and individual cases of innovative approaches to community development can be found throughout Slovakia. (Pongrácz, 2013).

\subsection{Practical examples}

Taken into consideration the above mentioned socio-economic and historical context, some practical case studies are presented in this chapter, which showcase the diverse richness of social innovation projects ongoing in Slovakia. Nevertheless, the common features of cases are that they reflect to relevant Slovak social problems referred above in a multi-dimensional way (that fosters the horizontal and vertical co-operation of several partners) in order to empower marginalized groups of people, such as minorities, vulnerable mothers or elderly people.

Cases examined in our paper are as follows: Social Housing in Rankovce, "Godmothers" project, enhancing attractiveness of the urban environment - "PrieStory", Mobile Application - TrashOut.me, and the Electronic monitoring services and signalization in care provision.

\section{Social housing project - "Building Hope"}

Building Hope is the pilot initiative in Slovakia to test a new model of self-help construction of family houses that can be seen as an alternative to state-subsidized construction of social rental dwellings. Building Hope is aimed at people living in very poor social conditions (Roma origin is not an explicit eligibility criteria).

It is implemented through a non-government organization ETP Slovakia, based in Košice co-operating for more than 12 years with Roma communities in Eastern Slovakia, operating community centres and providing comprehensive social services to the marginalized segments of society in five main areas: housing, education, employment, health and financial inclusion.

Thanks to this initiative, six young families from Rankovce in Košice-okolie district have transformed their future. The shacks they used to live in are no longer their homes; they have exchanged them for low-budget houses with 3E characteristics - ecological and energy efficient. Inspired by their achievement, other inhabitants from the settlement have also expressed an interest in building their own houses. 
Building Hope has been implemented since 2013 and ETP Slovakia believes that the project will continue by being financed from Slovakia's public funds. The financial resources for the project were provided mostly by private donors.

The involvement in activation programmes is an essential part of the programme. Building Hope does not only envisage empowerment of clients by upgrading them from passive by-standers to active participants in their home construction, but also by helping them acquire new skills and supporting their sense of responsibility (Kiss 2014). The outputs of this initiative are not only new decent housing conditions for "minority" inhabitants, but also changed relationships with the "majority", and better social atmosphere in the whole village. Developed capacities of Roma to work and maintain their houses, and to manage their budgets improved integration of this ethnic group into the local society.

Based on these activities, similar projects may fill the gap posed by the funding shortage, ineffectiveness and "hidden" racist motives of official government social housing programmes. In order for this to happen, the current "narrow" objectives of social housing should be re-assessed at state level, and the fundamental value of social housing projects in promoting social inclusion should be realized. (Szüdi, 2014).

\section{Support for abandoned mothers - "Godmothers"}

This innovative voluntary project is aimed at creating the permanent supportive network for abandoned mothers with little children in crisis situation, who mostly come from dysfunctional family or orphanage. "Godmothers" are the individual volunteers associated via the non-government organization "Chance for Unwanted", who create the key element in a so called non-institutionalized form of social inclusion service in this project. They serve as long term mentors for young women/mothers in social need, become friends of them and help them to create contacts and find a better place in society, overcome difficult life situations, advise with education of their children or holding a house. Godmothers are regularly supervised (at least once a month) and can get any required advice or help from managers and psychologists of "The Chance for Unwanted", who will provide mutual affectivity and emotional balance between mothers and volunteers.

The core outcomes of this project are integration of young mothers in social need and children staying with mothers instead of being placed into long term social care facilities, nonetheless the comprehensive material and non-material support to young mothers in social need to support their inclusion into the society.

This project also represents a new form of civic self-help, which can be easily implemented in various types of crisis centres. Hand in hand with educational activities, mentorship can be a proper way that will lead clients out of the circle of crisis centres to active life in the future. 
This project was initiated and implemented via a non-government organization "Chance for Unwanted", however other parties such as municipalities, governmental and private organizations and sponsors are involved, too. (Šanca OZ, 2014, Nemec et. al., 2013).

\section{Environmental project - mobile application "TrashOut.me"}

TrashOut.me belongs to Slovak start-up initiatives fighting against illegal dumps. Users are able to report dumps easily and fast by means of mobile application anywhere in the world. Specific function allows users marking a dump as cleared or not cleared yet, and then monitoring how the responsible authorities tackle the problem.

Due to this project, ordinary people, local governments and authorities, and other stakeholders can be easily involved and have positive impact on their environment.

An upgraded version of the application has broader usage and offers a possibility to localize dumps without connecting to the Internet. The new functions for instance enable to share reported dumps via social networks or email, to browse photos views, or to display the nearest dumps. All these novelties move the fight against illegal dumps forward to higher level.

TrashOut.me team cooperates with ministries, local governments, environmental organizations and waste companies in citizen's region and notifies citizens about the progress in cleaning of reported illegal dump.

At present, there are more than 10000 illegal dumps listed in the TrashOut.me database and over 400 illegal dumps reported as cleaned.

Application is currently available in English, Spanish, French, German, Czech and Slovak languages and the company operates in Slovakia, Czech Republic, Poland, Germany, Italy, Ireland, Austria, Romania, Albania, Canada, Australia and New Zeeland. (TrashOut.me, 2015).

\section{Attractiveness of the urban environment - "PrieStory"}

Public Spaces initiative ("PrieStory" in Slovak language) was launched by Ekopolis Foundation in 2005 as a brand new concept in Slovakia enabling realization of low cost investment projects executed by volunteers living in the area (the idea behind was that local volunteers are "best experts" to specify the concrete needs of their area). The principle of this initiative is that people if enabled to get involved in changing their surrounding will use the offered opportunity and put in their time, energy and work for its improvement. By providing necessary training, technical assistance and small financial contribution, the initiative helps to develop public spaces (mainly parks, playgrounds, small squares, etc.) that are proposed, designed, created and maintained by the communities themselves. 
The initiative endeavours to reach two main goals:

1. Revitalization of neglected public spaces and their transformation into vital meeting places.

2. Involvement of people living in the neighbourhood, surrounding blocks of flats or streets in the planning of this reconstruction.

In other words, not only the reconstruction and improved physical environment, but also cooperation of various stakeholders, and foremost active participation of the citizens in the planning andrevitalization of public spaces and their active interest and participation in public affairs belong to the expected outcomes of this initiative. The initiators are various local initiatives, the non-government organization Ekopolis and other actors including municipalities, banks and local sponsors providing additional funding depending on the type of the project. (Ekopolis, 2013).

\section{Electronic monitoring services in care provision}

The monitoring and signalization devices used in social care and health care represent the innovative concept of social service defined in Article 12 of the Act on Social services No. 448/2008 Coll. as different types of social services, which are as follows:

1. Monitoring and signalization of necessary assistance;

2. Crisis assistance provided via telecommunication technologies.

Two currently available technologies of electronic monitoring are present in Slovakia, i.e. one is a modern, portable "Electronic Guard" for seniors with a single SOS button calling wherever it is needed thanks to active localization, serving as a mobile phone as well, and another are wrist sensor bracelets attached to the landline aimed at calling for help from home.

These services are provided in several Slovak municipalities according to Article 52 of the above mentioned Act to a natural person with an unfavourable medical condition in order to prevent a critical social situation or to provide a solution for it. The monitoring and signalization of necessary assistance is the provision of constant, distance, voice, written (SMS message) or electronic communication with a natural person specified in clause 1 through signalization equipment or audio-visual equipment connected to central dispatching, which shall arrange the necessary assistance based on the signal. The need for social service provision is proved by the natural person by a confirmation of the health care provider pursuant to a special regulation. (Act on Social services No. 448/2008 Coll.).

Electronic Guard service works on electronic connection between localization device users and the dispatcher centre administered by municipal police (currently successfully running in four Slovak municipalities: Martin, Trebišov, Košice and Brezno, but many 
others are interested in implementation of the system due to positive proven results). Senior or disabled clients (users) carry the localization device, which captures the GPS signal, calculates its location and sends the data to the dispatcher application. If in need, user presses the alarm button and alerts the dispatcher operator. (Nemec et al., 2013).

Dispatcher employee monitors the real-time position of the user with the localization device. In case the client presses the alarm, dispatcher receives a notification in the application including a sound alert, showing which of the users need a help, where he/she currently is, and other information, such as age, health concerns, blood type, emergency instructions, etc.

This service is highly appreciated by the elderly citizens and citizens with disabilities, people with dangerous diagnoses with sudden health changes. Their relatives also appreciate the Electronic Guard service that gives them the permanent connection with the operator and the secure feeling whenever in need. In comparison with ordinary mobile devices and phones, the Electronic guide helps in cases when client is not able to communicate or describe health problem or location.

The output of this initiative is an improved life of elderly citizens, users with disabilities and their close relatives. The core actors involved in the provision of monitoring and signalization services involve local self-governments, IT companies and telecommunication providers. (Nemec et. al., 2013, Bahna et al., 2014).

\section{Summary and conclusions}

In the recent years, the social innovation approach did not only bring new governance methods across common fields of responsibilities with an active citizens 'participation "effective in addressing the challenges of green economy, social justice, active ageing, etc., but also the culture of trust and risk-taking which is needed to promote scientific and technological innovations". (Hubert, 2010).

The EU is currently engaged in a new growth strategy for a smart, sustainable and inclusive Europe by 2020 , where also the social issues take primary role and are brought to the fore. As results challenged the long-held belief that economic growth creates employment and wealth and mitigate poverty in all cases; the time has now come to try out new ways of bringing people out of poverty and promoting growth and well-being not only for-, but also with-, citizens.

Our contribution states only a few examples of social innovation initiatives implemented in Slovakia in different fields - empowered by people, social entrepreneurs and grassroots organizations aiming to developing participative solutions in addressing social demands and pressing societal issues (social housing for low income groups, new models of childcare, improvement of environmental quality, and modernization in elderly care).

They create a momentum and develop elements of a new paradigm for social intervention which could still be both more effective and efficient. (Vale, 2009). A 
contemporary trend is the role played by the public sector not only in supporting social innovations, but also in implementing new internal participatory processes that change the way in which actors interact. (Daglio et al., forthcoming 2015).

Many governments nowadays try to promote more openness, contestability and two-way dialogue, and some smaller EU countries lead the way in building innovation into their governmental strategies and national economies via new funds and supportive mechanism, nonetheless with open processes.

According to Hubert (2010) the public sector plays the key important role in this context, not only by providing the regulatory and financial frameworks necessary for social innovation to thrive, but also by allowing their own organizations to use "new models for pooling resources to improve accessibility, quality and affordability".

The world needs more social innovation to support solving the most vexing problems, such as population ageing in many countries, declining fertility, state of health care, diverse problems of children and education, rising corruption, etc. entrepreneurs, leaders, managers, civic activists and change agents, regardless of what sector they represent need to conquer the old patterns and stereotypes and put endeavour in finding new ways of creating social values.

Many of these problems require at first solutions at the national level. Herein we can state that the social innovations in Slovakia helped significantly in many cases to minimize the negative consequences. Some of the referred Slovak social innovations could serve as an inspiration or model to other countries in similar socio-economic circumstances. Social innovation can empower citizens and strengthen the economic and social fabric to cope with the European and global challenges, in particular in the current times of social, political and economic crisis.

\section{Acknowledgement}

Our article was prepared as a part of wider research (VEGA grant no. 1/0216/14) dealing with the innovation and modernisation of social services and as a part of international research project COST IS 1102.

\section{References}

Bahna, M. et al. (2014). Local Action Plan of Bratislava-Petržalka. Institut for Sociology, Slovak Academy of Sciences (PP12). Available from: http://www.sociologia.sav.sk/cms/uploaded/1456_attach_Local_Action_Plan_of_Bratislava_Petrzalka .pdf. [Accessed: $31^{\text {st }}$ August 2015].

Caulier-Grice, J. et al. (2012). Defining social innovation. A deliverable of the project: "The theoretical, empirical and policy founda---tions for building social innovation in Europe" (TEPSIE), European Commission - 7th Framework Programme, Brussels: European Commission, DG Research.

Committee for Scientific and Technological Policy (CSTP), Fostering Innovation to Address Social Challenges, OECD, Paris, 2011. 
Daglio, M.; Gerson D.; Kitchen H. (forthcoming, 2015). Building Organisational Capacity for Public Sector Innovation. Background Paper prepared for the OECD Conference: "Innovating the Public Sector: from Ideas to Impact". Paris, 12-13 November 2014.

DG Entreprise and Industry. (2014). Innovation Union Scoreboard. Available from: http://ec.europa.eu/enterprise/policies/innovation/files/ius/ius-2014_en.pdf. [Accessed: 30 th August 2015].

Ekopolis. (2013). Urban Spaces - Enhancing the Attractiveness and Quality of the Urban Environment. Available from: http://www.priestory.sk/en/index.html. [Accessed: 31 $1^{\text {st }}$ August 2015].

European Commission. (2013). Social Innovation Research in the European Union: Approaches, Findings and Future Directions; Policy Review. Luxembourg: Publications Office of the European Union.

European Commission. (2014). Social Innovation: A Decade of Changes. Luxembourg: Publications Office of the European Union.

Godin, B. (2012). Social Innovation: Utopias of Innovation from c.1830 to the Present. Project on the Intellectual History of Innovation Working Paper No. 11/2012.

Hochgerner, J. (2012). New Combinations of Social Practices in the KnowledgeSociety.In H.-W. Franz,J.Hochgerner \& J. Howaldt (Eds.),Challenge Social Innovation. Potentials for Business, Social Entrepreneurship, Welfare and Civil Society. Heidelberg, New York, Dordrecht, London: Springer, pp. 87-105.

Howaldt, J., Butzin, A., Domanski, D., \& Kaletka, C. (2014).Theoretical Approaches to Social Innovation-A CriticalLiteratureReview.A deliverable of the project: 'Social Innovation: Driving Force of Social Change' (SI-DRIVE).Dortmund: Sozialforschungsstelle.

Hubert, A. (2010). Empowering people, driving change: Social innovation in the European union, Working paper, Brussels.

Kiss, I. (2014). Policy of the Slovak Republic in Housing Sector. Bratislava: Economic Policy Institute. 19 SHGP 2014

Kuznets, S. (1974). Population, Capital and Growth: Selected Essays. London: Heinemann Educational.

Light, P. C. (2003). Reshaping Social Entrepreneurship." Stanford Social Innovation Review 4, pp. 47-51.

Mulgan, G. (2012).Social Innovation Theories: Can Theory Catch Up with Practice? In H.-W. Franz, J.Hochgerner, \& J. Howaldt (Eds.), Challenge Social Innovation.Potentials for Business, Social Entrepreneurship,Welfare and Civil Society(pp. 19-42).Berlin, New York: Springer.

Mulgan, G. et al. (2007). Social Innovation: What it Is, Why it Matters and How it Can Be Accelerated. Working paper, Skoll Centre for Social Entrepreneurship, Saïd Business School, University of Oxford.

Murray, R., Caulier-Grice, J. and Mulgan, G. (2010). The Open Book of Social Innovation. London: The Young Foundation and Nesta.

Nemec, J. et al. (2013). Social innovations on municipal level in Slovakia. European Commission - 7th Framework Programme, LIPSE or "Learning from Innovation in Public Sector Environments".

OECD. (2014) Economic Survey of the Slovak Republic 2014. Available from: http://www.oecd.org/eco/surveys/economic-survey-slovak-republic.htm. [Accessed: 31 $1^{\text {st }}$ August 2015]. 
Olejárova, D. (2013). Social Innovation in Slovakia, Part 1: The Context. Available from: http://youngfoundation.org/social-innovation-investment/social-innovation-in-slovakia-part-1-thecontext/. [Accessed: $1^{\text {st }}$ September 2015].

Phills J. A., Deiglmeier, K. and Miller, D. T. (2008). Rediscovering Social Innovation. Stanford Social Innovation Review.

Pol, E. et al. (2009). Social Innovation: Buzz Word or Enduring Term? The Journal of Socio-Economics, 38(6): pp. 878-885.

Pongrácz, E. (2013). Social entrepreneurship and corporate social responsibility in Slovakia. In Economic and social development: book of proceedings of the 2nd international scientific conference. Varazdin: Varazdin Development and Entrepreneurship Agency, Faculty of Commercial and Business Sciences, pp. 711-717.

Šanca OZ. (2014). Obtaining and supervising volunteers for mothers and children in a crisis situation. Available from: http://www.sancaoz.sk/en/project/godmothers. [Accessed: $31^{\text {st }}$ August 2015].

Schumpeter, J.A. (1934). The Theory of Economic Development. Harvard Economic Studies.

Szüdi, G. (2014) Assessment of Slovak social housing policy in terms of vertical and horizontal equity. In EDAMBA 2014: Proceedings of the international scientific conference for doctoral students and young researchers, Bratislava, pp. 558-564.

The Young Foundation (2012). Social Innovation Overview: A deliverable of the project: "The theoretical, empirical and policy foundations for building social innovation in Europe" (TEPSIE), European Commission - 7th Framework Programme, Brussels: European Commission, DG Research.

Vale, A. (2009). A new paradigm for social intervention in Social Innovation. In Social Innovation, New perspectives, Lisbon: Sociedade e Trabalho Booklets 12, pp. 3-13. 